\title{
Mitigation Potential of Nitrous Oxide Emissions from Irrigated Rice Fields by the DNDC-Rice Model
}

\author{
Kruamas Smakgahn
}

\begin{abstract}
The DNDC-Rice model was used to obtain mitigation potential of $\mathrm{N}_{2} \mathrm{O}$ emission from flooded rice fields under various water management regimes in central Thailand. The alternative water management (midseason drainage, multiple drainage, and local method) emitted approximately $61 \%$ of $\mathrm{N}_{2} \mathrm{O}$ emissions higher than conventional water management (continuously flooded). The short drainage period (local method) emitted the lowest emission compared to other treatments. There was no difference in crop carbon, harvest part, shoot and root portion among 4 treatments. Also, the efficiency of nitrogen uptake by the crop of all treatments was not different. The continuously flooded and short drainage period is an interesting candidate for mitigating $\mathrm{N}_{2} \mathrm{O}$ emissions from irrigated rice cultivation. However, multiple drainages are a remarkable effective practice to reduce greenhouse gases $\left(\mathrm{CH}_{4}\right.$ and $\left.\mathrm{N}_{2} \mathrm{O}\right)$ emissions from the rice field.
\end{abstract}

Index Terms-Alternative water regime, field drainage, greenhouse gas, nitrous oxide, mitigation.

\section{INTRODUCTION}

Nitrous oxide $\left(\mathrm{N}_{2} \mathrm{O}\right)$ contributes to the global warming of the atmosphere because it traps part of the thermal radiation from the earth's surface. On a per molecule basis, nitrous oxide is 310 times more potent than carbon dioxide [1]. Nitrous oxide is produced in the soil through nitrification and denitrification processes. Bacterial and chemical denitrification processes affect nitrate $\left(\mathrm{NO}_{3}{ }^{-}\right)$and nitrite $\left(\mathrm{NO}_{2}{ }^{-}\right)$under strictly anaerobic conditions. The nitrification process is the biological oxidation of ammonium $\left(\mathrm{NH}_{4}^{+}\right)$ resulting in nitrite or nitrate, which is then reduced to $\mathrm{N}_{2} \mathrm{O}$ and nitrogen gas through denitrification. Denitrification is an anaerobic process where nitrate is reduced to $\mathrm{N}_{2}$ via $\mathrm{NO}$ and $\mathrm{N}_{2} \mathrm{O}$. NO, and $\mathrm{N}_{2} \mathrm{O}$ are emitted if denitrification is incomplete. $\mathrm{NO}_{3}{ }^{-}, \mathrm{NO}$, and $\mathrm{N}_{2} \mathrm{O}$ act as electron acceptors when there is not enough oxygen. Denitrification is a function of oxygen supply, carbon availability, temperature, $\mathrm{pH}$, water content and concentration of $\mathrm{NO}_{3}^{-}, \quad \mathrm{NO}$ and $\mathrm{N}_{2} \mathrm{O}$. High concentrations of available organic carbon, $\mathrm{pH}$ between 6 and 8 , temperature above $10{ }^{\circ} \mathrm{C}$ and water content of more than $80 \%$ support denitrification [2]. In addition, $\mathrm{N}_{2} \mathrm{O}$ is produced from the nitrifier denitrification process, the pathway of nitrification. In this process, the oxidation of $\mathrm{NH}_{3}$ to $\mathrm{NO}_{2}^{-}$is followed by the reduction of $\mathrm{NO}_{2}{ }^{-}$to $\mathrm{N}_{2} \mathrm{O}$.

In rice fields, $\mathrm{N}_{2} \mathrm{O}$ emissions mainly occurred during non-flooding/fallow periods [3] or drainage period [4], [5], when the soil exposed the air a very long time [6]. High $\mathrm{N}_{2} \mathrm{O}$

Manuscript received August 13, 2019; revised January 8, 2020.

Kruamas Smakgahn is with Faculty of Liberal Arts and Science, Kasetsart University Kamphaeng Saen Campus, Kamphaeng Saen District, Nakhon Pathom Province, 73140, Thailand (e-mail: faaskms@ku.ac.th). emission was observed from intermittent irrigation [5], [7]. $\mathrm{N}_{2} \mathrm{O}$ emissions derived from agriculture are $>75 \%$ of anthropogenic sources, but the prediction of $\mathrm{N}_{2} \mathrm{O}$ emissions is not yet reliable. If some combination of agricultural management practices, such as matching $\mathrm{N}$ supply with crop demand, tightening $\mathrm{N}$ flow cycles, using advanced fertilization techniques and optimizing tillage irrigation and drainage were adopted, the emission could decrease by almost $20 \%$ [8].

The objective of this study is to obtain the mitigation potential of $\mathrm{N}_{2} \mathrm{O}$ emission under various water management regimes by the DNDC-Rice model.

\section{MATERIALS AND METHODS}

DNDC-Rice model [9] was validated for $\mathrm{N}_{2} \mathrm{O}$ emissions against field observations data in 2002 from irrigated rice field at Samutsakorn province in the central plain of Thailand (see [5] for details of field observation). This field experiment was investigated with four different water management under the same cultivar type and soil properties in the wet season. Four different field drainage regimes were conducted: the local method (LM), continuous flooding (CF), mid-season drainage (MSD) and multiple aerations or multiple drainages (MTD). LM treatment in this area consists of flooding with flexible short drainage during a growing period. MSD treatment was conducted at 64 days after planting (flowering stage) for 6 days. MTD consisted of two intermittent drainage periods of three days duration conducted at 21 days and 64 days after initial flooding. The final drainage was applied for all treatment at 15 days before harvesting. This field experiment was planted after rice straw from the previous growing season was burned therefore rice was planted without rice straw incorporation. The AP fertilizer was applied at 20 days after planting as the basal fertilizer $\left(25 \mathrm{~kg} \mathrm{~N} \mathrm{ha}^{-1}\right)$. Nitrogen as urea fertilizer was applied as the top dressing fertilizer at 29 days after planting (DAP). The AP fertilizer was applied again at 47 DAP as the top-dressing fertilizer. The photoperiod insensitive non-jasmine rice cultivar Suphanburi1 (Sp1) was used. Wet seeding with $187.5 \mathrm{~kg} \mathrm{ha}^{-1}$ was applied on August 12, 2002. The fields were flooded 7 DAP and the water level in each field was controlled $(5-10 \mathrm{~cm})$, except for during drainage periods. Rice soil in this field experiment was Bangkok (Bk) soil series and the soil was classified as Typic Tropaquepts. This soil contained $1.31 \%$ of organic carbon and $0.06 \%$ nitrogen content under an initial soil $\mathrm{pH}$ of 6.10. Soil texture was classified as clay with a percentage composition of sand: silt: clay of 22: 24: 54 (Table I). (see [5] for the characteristic of the agriculture management). 
The database component for the regional mode of DNDC-Rice model simulation contained daily weather data in the planted year for all cases. Soil properties (Land development department), farming practices (such as fertilizer application, planting data, tillage data), and water management in study area derived from governmental agencies were used for simulations. The fraction of the above-ground litter or crop residue returned to the field after harvest was assumed to $25 \%$. The water leaking problem has been defined as moderate $\left(2-10 \mathrm{~mm} \mathrm{day}^{-1}\right)$. Default of the model has been applied if lack of information from field observations included climate data ( $\mathrm{N}$ concentration in rainfall, atmospheric background of $\mathrm{NH}_{3}$ and $\mathrm{CO}_{2}$ concentration), soil data (soil wilting point, field capacity, soil bypass flow, initial soil $\mathrm{NO}_{3}{ }^{-}, \mathrm{NH}_{4}{ }^{+}$concentration), crop data (initial photosynthesis efficiency, maximum photosynthesis rate, development rate in vegetative stage, development rate in reproductive stage).

The essential data input for the DNDC-rice model is that the reduction of electron acceptors such as $\mathrm{Fe}^{3+}, \mathrm{Mn}^{4+}$, and $\mathrm{SO}_{4}{ }^{2-}$ affects the $\mathrm{CH}_{4}$ production rate. Hence, the DNDC-rice model requires data on soil concentrations of $\mathrm{Fe}^{3+}, \mathrm{Mn}^{4+}$, and $\mathrm{SO}_{4}{ }^{2-}$ as input parameters. These data were derived from previous field observations in Thailand. The manure amendment information was not concerned in this study because no organic amendment and manure as organic fertilizer were applied before or during the growing season. In addition, weeding and grazing information were not concerned with the simulations.

TABLE I: SOIL PROPERTY IN THE STUDY SiTE [5]

\begin{tabular}{|l|c|c|}
\hline \multicolumn{1}{|c|}{ Soil property } & Unit & \\
\hline $\mathrm{pH}$ & & 6.1 \\
\hline Organic matter & $\%$ & 2.3 \\
\hline Organic carbon & $\%$ & 1.31 \\
\hline Nitrogen (N) & $\%$ & 0.06 \\
\hline Potassium (K) & $\mathrm{ppm}$ & 800 \\
\hline Phosphorus (P) & $\mathrm{ppm}$ & 7 \\
\hline Magnesium (Mg) & $\mathrm{ppm}$ & 504 \\
\hline $\mathrm{NH}_{4}{ }^{+}-\mathrm{N}(\mathrm{ppm} \mathrm{N})$ & $\mathrm{ppm} \mathrm{N}$ & 19.6 \\
\hline
\end{tabular}

\section{RESULTS AND DISCUSSION}

\section{A. Total Nitrous Oxide Emissions}

Total seasonal $\mathrm{N}_{2} \mathrm{O}$ emissions estimated by the DNDC-Rice model were underestimated compared with field observation in most cases. Lowest seasonal $\mathrm{N}_{2} \mathrm{O}$ emissions were observed from the local method $\left(0.033 \mathrm{~g} \mathrm{ha}^{-1}\right)$ and the highest emission was observed from the midseason drainage treatment $\left(0.051 \mathrm{~g} \mathrm{ha}^{-1}\right)$. Multiple drainages emitted almost equal $\mathrm{N}_{2} \mathrm{O}$ emission from continuously flooded; 0.037 and $0.038 \mathrm{~g} \mathrm{ha}^{-1}$, respectively. Validated $\mathrm{N}_{2} \mathrm{O}$ emission by the DNDC-Rice model shown more than $50 \%$ underestimation compared to field observation data in all cases. But the lowest emission derived from continuously flooded and about 10 times lower than higher than alternative water management. The multiple drainage treatment and the local method emitted almost the same level as midseason drainage but the midseason drainage treatment emitted $\sim 30 \%$ higher than from the local method. While the multiple drainages and continuously flooded treatments emitted almost the same level and $\sim 10 \%$ higher than the local method (Fig. 1).

\section{B. Seasonal Pattern of Nitrous Oxide Emissions}

The results from the DNDC-Rice model validation agree with field observations, that $\mathrm{N}_{2} \mathrm{O}$ emission from the drainage treatments (midseason drainages and multiple drainages) were high. Validated data and field measurements indicated that midseason drainage and multiple drainages can be used to predict $\mathrm{N}_{2} \mathrm{O}$ flux patterns. The low amount of $\mathrm{N}_{2} \mathrm{O}$ emitted during the flooding period but it began increasing gradually during the drainage period and then decreased when the fields were re-flooded (Fig. 2). However, the simulation data by the DNDC-Rice model showed that the model could not predict all pulses of $\mathrm{N}_{2} \mathrm{O}$ including the presented timing of pulses. The results of this study coincide with the research of [4] that the high $\mathrm{N}_{2} \mathrm{O}$ pulses both timing and magnitude could not be predicted by the model. The reason for underprediction may cause of the inaccuracy of rice growth. The higher simulated rice growth showed that the nitrogen in the soil was used by the plant and fewer nitrogen contents remain for microbial activity in soil [4]. Even though the observation data presented $\mathrm{N}_{2} \mathrm{O}$ emissions but the model cannot predict. These are because the flooded condition does not induce the nitrification process and less $\mathrm{NO}_{3}$ for denitrification under flooded conditions [4].

The overall results of emissions prediction consisted of other research that zero $\mathrm{N}_{2} \mathrm{O}$ emissions were simulated by the DNDC model under continuously flooded rice fields [10], low $\mathrm{N}_{2} \mathrm{O}$ fluxes that were observed [5] during permanent flooding, were probably due to the reduction of $\mathrm{N}_{2} \mathrm{O}$ to $\mathrm{N}_{2}$ under low soil Eh [11], [12] and also due to less availability of $\mathrm{NO}_{3}{ }^{-}$for denitrification [13].

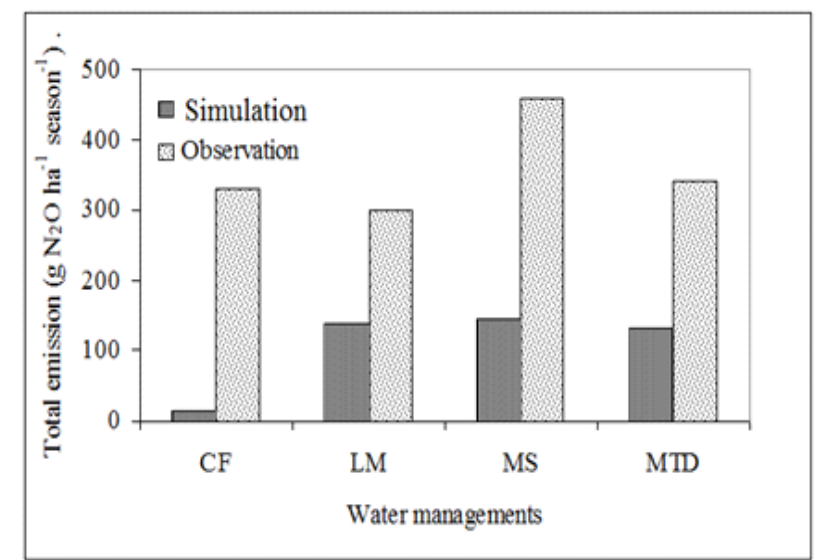

Fig. 1. Nitrous oxide emissions from field observations and the DNDC-Rice model Validated under different water management regimes.

The results from measurements at Samutsakorn experiment and predictions by the DNDC-Rice model were in agreement with previous research, suggesting that $\mathrm{N}_{2} \mathrm{O}$ emissions mainly occurred during non-flooding periods or fallow periods [14] and no emission of $\mathrm{N}_{2} \mathrm{O}$ was detected in the rice paddy field under anaerobic conditions [7]. Emissions of $\mathrm{N}_{2} \mathrm{O}$ were influenced by water content and soil Eh [15], [16] and the peak of $\mathrm{N}_{2} \mathrm{O}$ in paddy soils during midseason aeration could be attributed to the occurrence of optimum soil moisture under sufficient $\mathrm{N}$ availability, favorable for the production and accumulation of $\mathrm{N}_{2} \mathrm{O}$ [14]. The use of nitrification inhibitor under wet irrigation reduced 
$\mathrm{N}_{2} \mathrm{O}$ emission [17]. Subsequent delayed flooding or intermittent irrigation can contribute to significantly reduce the global warming potential of rice cropping systems concerning continuous flooding [18], [19].

In general, draining the rice fields may create a suitable $\mathrm{O}_{2}$ availability in the soil for $\mathrm{N}_{2} \mathrm{O}$ production as an intermediate product in either nitrification or denitrification. While maintaining flooded conditions may create strict anaerobic conditions and restrict $\mathrm{N}_{2} \mathrm{O}$ formation and emission [14]. In the case of multiple drainages (despite two short drainage times ( 3 days) being employed), the $\mathrm{N}_{2} \mathrm{O}$ emissions were lower than in the midseason drainage treatment with a one-time drainage of 6 days. Shorter drainage time might not be sufficient for $\mathrm{N}_{2} \mathrm{O}$ to develop. Therefore, multiple drainages showed lower $\mathrm{N}_{2} \mathrm{O}$ emissions compared to midseason drainage. In contrast, the long draining period (6 days) lead to lower $\mathrm{CH}_{4}$ emissions compared to the 3-days draining period.

Field observation data from South India reported that the alternate wetting and drying irrigation-induced $\mathrm{N}_{2} \mathrm{O}$ emissions [20], and field observation in Vietnam also reported that multiple aerations increased $\mathrm{N}_{2} \mathrm{O}$ emissions by $1.5 \%$ [21]. The intermittent irrigation increases $\mathrm{N}_{2} \mathrm{O}$ emission by $23.72 \%$ respected continuously flood [22]. Even though continuously flooded trends to reduce $\mathrm{N}_{2} \mathrm{O}$ emission compared to alternative water management but it promoted anaerobic conditions suitable for $\mathrm{CH}_{4}$ emission [5], [23]. The intermittent irrigation reduced total seasonal $\mathrm{CH}_{4}$ emission by $24.22 \%$ compared to continuously flooded [22]. Modeling tests agree with previous research that trade-off daily $\mathrm{N}_{2} \mathrm{O}$ flux and daily $\mathrm{CH}_{4}$ flux occurred in rice fields (Fig. 3) and indicate that field drainage induced $\mathrm{N}_{2} \mathrm{O}$ fluxes.

The result concluded that multiple drainages (two intermittent drainage periods of three days duration) in the flooded rice field is an interesting option for $\mathrm{N}_{2} \mathrm{O}$ mitigation. In addition, multiple drainages is a remarkable effective practice to reduce greenhouse gases $\left(\mathrm{CH}_{4}\right.$ and $\left.\mathrm{N}_{2} \mathrm{O}\right)$ emissions from the rice field.

\section{Rice Growth and Yield}

Simulated rice grain yield or harvest part by DNDC-Rice model from continuously flooded, local method, and mid-season drainage were almost similar, but the multiple drainage treatment reduced approximately $1 \%$ compared to others (Table II). However, a field experiment in Thailand at Samutsakorn province [5] reported rice yield under midseason drainage and multiple drainages were reduced by 6.86 to $11.43 \%$, respective concerning conventional water management. Multiple drainages decreased panicle number but the DNDC-Rice model calculates just the tiller number but not panicle number, which is importance parameter for grain yield calculation. Thus, rice grain yield calculation may not be accurate.

Furthermore, the model does not calculate photosynthesis in the vegetative period to the panicle period but just calculates only for tiller number but photosynthesis does not limit by the panicle or tiller number, therefore, the model unable to predict rice grain yield from drainage treatments, especially for multiple drainages. The observation data [5] reported shoot and root dry weight from 4 treatments were not significantly different. However, multiple drainages reduced of $3.52 \%$ of shoot dry weight compared to continuously flooded, while, mid-season drainage induced of $3.35 \%$ of shoot dry weight over continuously flooded.

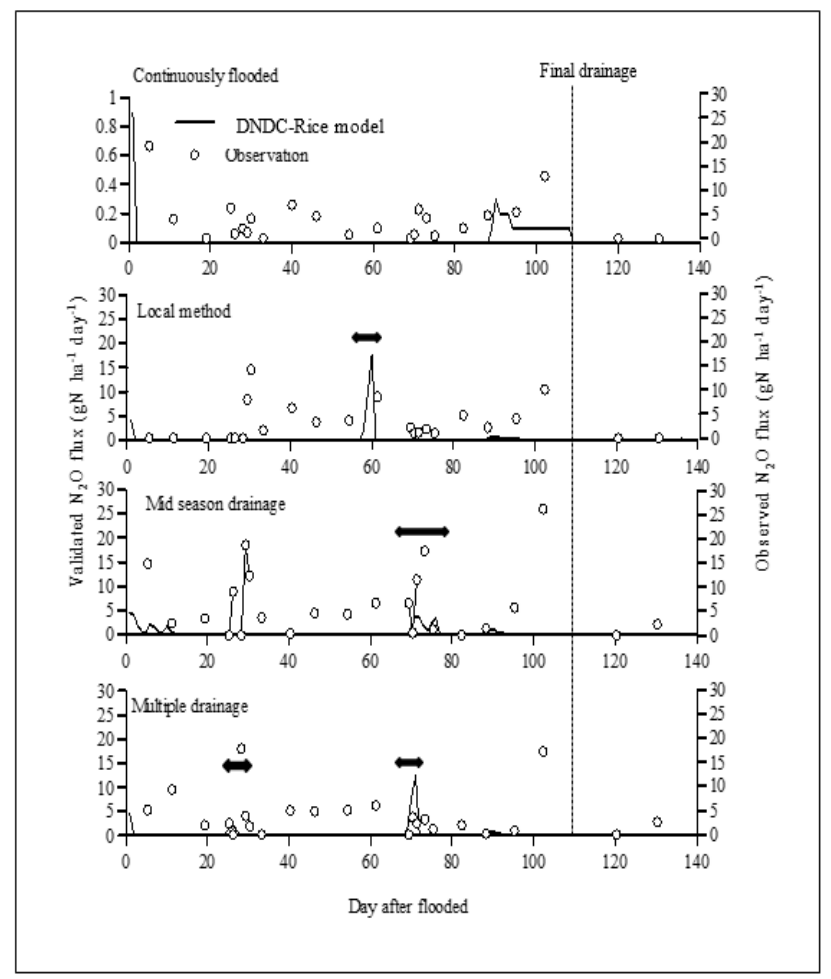

Fig. 2. Comparison of observed daily nitrous oxide fluxes and simulated by the DNDC-Rice model under different water management regimes at Samutsakorn rice field. (Dark two-way arrow indicated drainage duration).

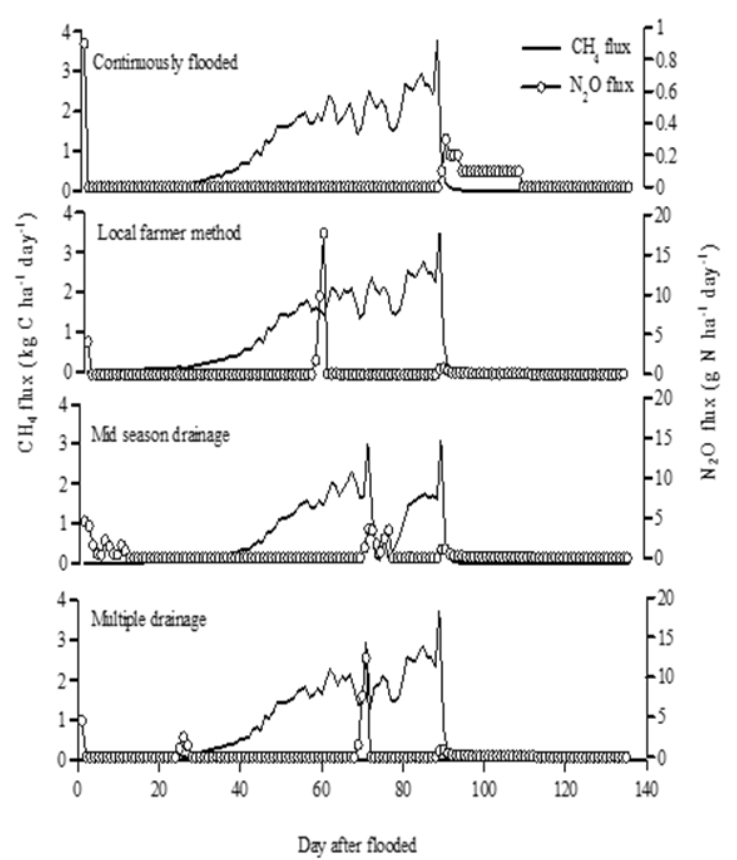

Fig. 3. Simulated seasonal variation of nitrous oxide and methane emission from Samutsakorn rice field under different water management regimes.

The DNDC-Rice model agreed with field observation that multiple drainages reduced shoot weight but only $0.2 \%$ respect to continuously flooded. While mid-season drainage induced shoot weight of $0.2 \%$ higher than continuously flooded. The root weight was increased by $0.40 \%$ over the continuously flooded by model simulation but increased by more than $11 \%$ when obtained from field observed. And the 
observation data reported multiple drainage management increased root weight but the model simulation showed the opposite result. However, the model simulation data was not shown the large difference in shoots and root portion among four treatments.

TABLE II: Simulated VALUE OF CROP CARBOn, HARVEST PART, SHOOT, ROOT WEIGHT, N UPTAKE BY CROP, AND OBSERVED VALUE OF GRAIN

\begin{tabular}{|c|c|c|c|c|}
\hline \multicolumn{5}{|c|}{ YIELD } \\
\hline Parameters & $\mathrm{CF}$ & LM & MS & MTD \\
\hline Crop C $\left(\mathrm{kg} \mathrm{C} \mathrm{ha}^{-1}\right)$ & 2,259 & 2,267 & 2,265 & 2,253 \\
\hline Harvest part $\left(\mathrm{kg} \mathrm{C} \mathrm{ha}^{-1}\right)$ & 791 & 793 & 793 & 789 \\
\hline Shoot $\left(\mathrm{kg} \mathrm{C} \mathrm{ha}^{-1}\right)$ & 971 & 975 & 974 & 969 \\
\hline $\operatorname{Root}\left(\mathrm{kg} \mathrm{C} \mathrm{ha}^{-1}\right)$ & 497 & 499 & 498 & 496 \\
\hline $\begin{array}{l}\mathrm{N} \text { uptake by crop }(\mathrm{kg} \mathrm{N} \\
\left.\mathrm{ha}^{-1}\right)\end{array}$ & 160.6 & 162.18 & 162.39 & 160.38 \\
\hline $\begin{array}{l}\text { Observed grain yield }(\mathrm{kg} \\
\left.\mathrm{ha}^{-1}\right)[5]\end{array}$ & 4,350 & 4,375 & 4,075 & 3,875 \\
\hline
\end{tabular}

Remarks: CF: continuously flooded, LM: local method, MS: midseason drainage, MTD: multiple drainages.

Simulated N uptake by crop among four treatments were not large differences, and it is related to the weight and root weight of plants (Table II). The multiple drainages reduced $0.14 \%$ of $\mathrm{N}$ uptake by crop compared to continuously flood but the local method and mid-season drainage induced $0.98 \%$ and $1.11 \%$ over continuously flooded, respectively. The higher simulated rice growth from local method and mid-season drainage results in higher nitrogen uptake by the plants [4].

\section{Global Warming Potential}

This study calculated the GWP values of $\mathrm{N}_{2} \mathrm{O}$ and $\mathrm{CH}_{4}$ emissions from the simulated results compare to the observation data. The $\mathrm{N}_{2} \mathrm{O}$ emissions $\left(\mathrm{kg} \mathrm{N} \mathrm{ha}^{-1}\right)$ and $\mathrm{CH}_{4}$ were converted to the equivalent $\mathrm{CO}_{2}$ emission $(\mathrm{kg} \mathrm{CO}$ eq $\mathrm{ha}^{-1}$ ) by multiplying these values by 21 and 310 , then considering the GWPs for a 100 year time horizon [24]. The GWP of simulated $\mathrm{N}_{2} \mathrm{O}$ and the observation is shown in Table III.

TABLE III: GLOBAL WARMING POTENTIAL

\begin{tabular}{|l|c|c|c|c|c|c|}
\hline \multirow{2}{*}{ Treatments } & \multicolumn{3}{|c|}{ Observed value [5] } & \multicolumn{3}{c|}{ Simulated value } \\
\cline { 2 - 7 } & $\mathrm{CH}_{4}$ & $\mathrm{~N}_{2} \mathrm{O}$ & $\begin{array}{c}\mathrm{N}_{2} \mathrm{O} / \\
\text { Total } \\
(\%)\end{array}$ & $\mathrm{CH}_{4}$ & $\mathrm{~N}_{2} \mathrm{O}$ & $\begin{array}{c}\mathrm{N}_{2} \mathrm{O} / \\
\text { Total } \\
(\%)\end{array}$ \\
\hline $\mathrm{CF}$ & $5,115.59$ & 115.16 & 2.20 & 6,972 & 15.5 & 0.22 \\
\hline LM & $5,030.54$ & 102.43 & 1.99 & 6,846 & 18.6 & 0.27 \\
\hline MS & $3,646.12$ & 159.28 & 4.19 & 6,090 & 15.5 & 0.25 \\
\hline MTD & $3,292.49$ & 119.30 & 3.50 & 6,888 & 18.6 & 0.27 \\
\hline
\end{tabular}

Remarks: CF: continuously flooded, LM: local method, MS: midseason drainage, MTD: multiple drainages.

The simulated net global warming potentials (GWPs) were higher than that of the observation data but not large differences among the four treatments. While net GWPs from field observations were large differences between conventional (continuously flooded and local method) and alternatives water management (Mid-season drainage and multiple drainages). The observed GWP of $\mathrm{N}_{2} \mathrm{O}$ was about $1.99-4.19 \%$ of the total, but the simulated value was only $0.22-0.27 \%$ of total GWPs. The highest GWP of $\mathrm{N}_{2} \mathrm{O}$ was observed from mid-season drainage, however, the highest predicted value derived from the local method and multiple drainages. The GWP of $\mathrm{N}_{2} \mathrm{O}$ under mid-season drainage from field observation increased by $90.45 \%$ compared to continuously flood but increased only by $13.63 \%$ when predicted by the model. Therefore, model modification of the process of nitrification and denitrification of the model simulation is required to more accuracy of calculation of $\mathrm{N}_{2} \mathrm{O}$ emission.

\section{CONCLUSION}

The data prediction by the DNDC-Rice model was agreed with field observations that $\mathrm{N}_{2} \mathrm{O}$ emissions from alternative water management regimes were higher than continuously flooded (conventional water management regime). Alternative water management induced $\sim 60 \%$ of $\mathrm{N}_{2} \mathrm{O}$ emissions compared to conventional water management regimes. The results from field observed and the DNDC-Rice model simulation was in agreement with previous research, suggesting that $\mathrm{N}_{2} \mathrm{O}$ emissions mainly occurred during non-flooding periods or drainage period. Therefore, water management in a rice field during the growing period played an important role in $\mathrm{N}_{2} \mathrm{O}$ emissions under the same soil condition. The outcomes of this study suggest that controlled water supplied in flooded rice soil as continuously flooded conditions and short wet-dry conditions are a reasonable way to mitigate $\mathrm{N}_{2} \mathrm{O}$ emission from irrigated rice fields. The result also suggested that the modifications of the DNDC-Rice model's feature of $\mathrm{N}_{2} \mathrm{O}$ calculation in case of drainage management, the feature of photosynthesis, panicle number, and grain yield prediction are required to obtained better prediction accuracy of $\mathrm{N}_{2} \mathrm{O}$ emission and grain yield.

\section{CONFLICT OF INTEREST}

"The author declares no conflict of interest".

\section{AUTHOR CONTRIBUTIONS}

K. Smakgahn conducted the research, analyzed the data, prepared the manuscript and approved the final version.

\section{ACKNOWLEDGMENT}

Thank you, Dr. Kazuyaki Yagi and Dr. Tamon Fumoto National Institute for Agro-Environmental Sciences, 3-1-3 Kannondai Road, Tsukuba, Ibaraki 305-8604, Japan for their kind suggestions and the DNDC-Rice model. Thanks, Dr. Chitnucha Buddhaboon (IRRI Thailand) for his kind suggestions on rice crop data for simulation.

\section{REFERENCES}

[1] IPCC, Climate Change, Working Group I: The Physical Science Basis, 2007.

[2] A. F. Bouwman, "Direct emission of nitrous oxide from agricultural soils," Nutrient Cycling in Agroecosystems, vol. 46, pp. 53-70, 1996.

[3] G. X. Chen, B. Huang, H. Xu, Y. Zhang, G. H. Huang, K. W. Yu, A. X. Hou, R. Du, S. J. Han, and O. Cleemput, "Nitrous oxide emissions from terrestrial ecosystems in China," Chemosphere Global Change Science, vol. 2, pp. 373-378, 2000.

[4] N. Katayanagi, Y. Furukawa, T. Fumoto, and Y. Hosen, "Validation of the DNDC-Rice model by using $\mathrm{CH}_{4}$ and $\mathrm{N}_{2} \mathrm{O}$ flux data from rice cultivated in pots under alternate wetting and drying irrigation management," Soil Science and Plant Nutrition, vol. 58, no. 3 pp. 360-372, 2012. 
[5] S. Towprayoon, K. Smakgahn, and S. Poonkaew, "Mitigation of methane and nitrous oxide emissions from drained irrigated rice fields," Chemosphere, vol. 59, pp. 1547-1556, 2005.

[6] R.-H. Jorge, "Methane and nitrous oxide fluxes from water, plants, and soils of a constructed treatment wetland in phoenix, AZ," Ph.D. dissertation, Arizona State University, 2017.

[7] H. Tsuruta, K. Kanda, and T. Hirose, "Nitrous oxide emission from rice paddy fields in Japan," Nutrient Cycling in Agroecosystems, vol. 49, pp. 51-58, 1997.

[8] L. Erda, L. Yue, and D. Hongmin, "Potential GHG mitigation options for agriculture in China," Applied Energy, vol. 56(3/4), pp. 423-432, 1997.

[9] T. Fumoto, K. Kobayashi, C. S. Li, K. Yagi, and T. Hasegawa, "Revising a process-based biogeochemistry model (DNDC) to simulate methane emission from rice paddy fields under various residue managements and fertilizer regimes," Global Change Biology, vol. 4, pp. 382-402, 2008.

[10] Y. Jagadeesh, C. Li, S. Frolking, D. Nayak, and T. Adhya, "Field validation of DNDC model for Methane and nitrous oxide emissions from rice-based production systems of India," Nutrient Cycling in Agroecosystems, vol. 74, pp. 157-174, 2006.

[11] X. Zheng, W. Mingxing, W. Yuesi, S. Renxing, L. Jing, J. Heyer, M. Koegge, H. Papen, J. Jisheng, and L. Laotu, "Mitigation options for methane, nitrous oxide and nitric oxide emissions from agricultural ecosystems," Advance in Atmospheric Sciences, vol. 17, pp. 84-92, 2000.

[12] A. X. Hou, G. X. Chen, Z. P. Wang, O. Cleemput, and W. H. Patrick, "Methane and nitrous oxide emissions from a rice field in relation to soil redox and microbiological process," Soil Science Society of American, vol. 64, pp. 2180-2186, 2000

[13] S. Ghosh, D. Majumdar, and M. C. Jain, "Methane and nitrous oxide emission from irrigated rice of north India," Chemosphere, vol. 51, pp. 181-195, 2003.

[14] G. X. Chen, B. Huang, H. Xu, Y. Zhang, G. H. Huang, K. W. Yu, A. X. Hou, R. Du, S. J. Han, and O. Cleemput, "Nitrous oxide emissions from terrestrial ecosystems in China," Chemosphere Global Change Science, vol. 2, pp. 373-378, 2000.

[15] D. Majumdar, S. Kumar, H. Pathak, M. C. Jain, and U. Kumar, "Reducing nitrous oxide emission from an irrigated rice field of North India with nitrification inhibitors," Agriculture, Ecosystem and Environment, Vol. 81, pp. 163-169, 2000.

[16] W. K. Ma, A. Schautz, L. E. Fishback, A. Bedard-Haughn, R. E. Farrell, and S. D. Siciliano, "Assessing the potential of ammonia oxidizing bacteria to produce nitrous oxide in soils of high arctic lowland ecosystem on Devon Island," Canada. Soil Biol Biochem., vol. 39, pp. 2001-2013, 2007.

[17] G. Liu, H. Yu, G. Zhang, H. Xu, and J. Ma, "Combination of wet irrigation and nitrification inhibitor reduced nitrous oxide and methane emissions from a rice cropping system," Environ Sci Pollut Res., vol. 23, pp. 17426-17436, 2016.

[18] A. Hadi, K. Inubushi, and K. Yagi, "Effect of water management on greenhouse gas emissions and microbial properties of paddy soils in japan and Indonesia," Paddy and Water Environment, vol. 8, pp. 319-324, 2010
[19] M. Peyron, C. Bertora, S. Pelissetti, D. Said-Pullicino, L. Celi, E. Miniotti, M. Romani, and D. Sacco, "Greenhouse gas emissions as affected by different water management practices in temperate rice paddies," Agriculture, Ecosystem and Environment, vol. 232, pp. 17-28, 2016

[20] A. Oo, S. Sudo, K. Inubushi, M. Mano, A. Yamamoto, K. Ono, T. Osawa, S. Hayashida, P. Patra, Y. Terao, P. Elayakumar, K. Vanitha, C. Umamageswari, P. Jothimani, and V. Ravi, "Methane and nitrous oxide emissions from conventional and modified rice cultivation systems in South India," Agriculture, Ecosystems \& Environment, vol. 252. 10.1016/j.agee.2017.10.014, 2018.

[21] J. Dill, G. Deichert, and L. T. N. Thu, Promoting the System of Rice Intensification: Lessons Learned from Tra Vinh Province, Viet Nam, German Agency for International Cooperation (GIZ) and International Fund for Agricultural Development (IFAD): Hanoi, 2013.

[22] Z. Jiao, A. Hou, Y. Shi, G. Huang, Y. Wang, and X. Chen, "Water management influencing methane and nitrous oxide emissions from rice field in relation to soil redox and microbial community," Communications in Soil Science and Plant, vol. 37, pp. 1890-1903, 2006.

[23] P. Gundersen, R. Christiansen, G. Alberti, N. Bruggemann, S. Castaldi, R. Gasche, B. Kitzler, L. Klemedtsson, R. Lobo-do-Vale, F. Moldan, T. Rutting, P. Schleppi, P. Weslien, and Zechmeister-Boltenstern, "The response of methane and nitrous oxide fluxes to forest change in Europe," Biogeosciences, vol. 9, pp. 3999-4012, 2012.

[24] J. Houghto, L. G. M. Filho, B. A. Canllander, N. Harris, A. Fattenberg, and K. Maskell, Climate Change 1995: The Science of Climate Change, Cambridge University Press, New York.

Copyright (C) 2020 by the authors. This is an open access article distributed under the Creative Commons Attribution License which permits unrestricted use, distribution, and reproduction in any medium, provided the original work is properly cited (CC BY 4.0).

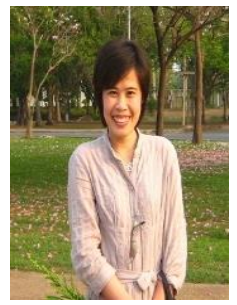

Kruamas Smakgahn was born in Lopburi province, Thailand. She graduated the $\mathrm{Ph} . \mathrm{D}$. in environmental technology from The Joint Graduate School of Energy and Environment, King Mongkut's University of Technology Thonburi, Bangkok, Thailand (January 25, 2005). After finishing a Ph.D. she was granted by the Japanese Government for Eco-Frontier Fellowship and she joined Greenhouse Gas Emissions Team, Carbon and Nutrient Cycles Division, Department of Global Resources, National Institute for Agro-Environmental Sciences, Tsukuba, Ibaraki, Japan for 2 years. Now, she works for the governmental university in Thailand as assistant professor at the Department of Science, Faculty of Liberal Arts and Science, Kasetsart University Kamphaeng Sean Campus, Kamphaeng Saen District, Nakornpathom province, Thailand. Her latest interest is biogeochemistry of greenhouse gases (GHGs), GHG emissions from the agricultural sector and forest, GHGs mitigation and adaptation. 